\title{
Tolerance to the protective effects of salmeterol on methacholine-induced bronchoconstriction: influence of inhaled corticosteroids
}

\author{
L-P. Boulet*, A. Cartier+, J. Milot*, J. Côté*, J-L. Malo+, M. Laviolette*
}

Tolerance to the protective effects of salmeterol on methacholine-induced bronchoconstriction: influence of inhaled corticosteroids. L-P. Boulet, A. Cartier, J. Milot, J. Côté, J-L. Malo, M. Laviolette. CERS Journals Ltd 1998.

ABSTRACT: Long-acting $\beta_{2}$-adrenoceptor agonists such as salmeterol reduce airway responsiveness for at least $12 \mathrm{~h}$, but this effect seems to decrease with regular use. We evaluated the time-course of the protective effects of salmeterol on methacholineinduced bronchoconstriction, its modulation by inhaled corticosteroids (ICS) and its influence on asthma control.

Thirty two subjects (13 males and 19 females) with mild to moderate stable asthma were divided into two groups according to their medication needs: bronchodilators (BD) alone $(n=16)$ or with ICS $(n=16)$. After a 2 week run-in period, a double-blind crossover study was conducted. Subjects from both groups received salmeterol 50 $\mu \mathrm{g}$ b.i.d. or a placebo for 4 weeks each in random order, separated by a 2 week washout period. The provocative concentration of methacholine causing a $20 \%$ fall in forced expiratory volume in one second (PC20) was measured before and after each treatment period, $1 \mathrm{~h}$ prior to inhalation of salmeterol or placebo and 1 and $12 \mathrm{~h}$ after.

Baseline forced expiratory volume in one second (FEV1) increased significantly after salmeterol, both after the first dose and at 4 weeks (BD group: 19 and 17\%; ICS: 22 and $13 \%$ ). On the first day of administration, salmeterol provided significant protection in both groups up to $12 \mathrm{~h}$ with a PC20 before and 1 and $12 \mathrm{~h}$ postdose of 2.2, 21.7 and 12.4, $\mathrm{mg}^{-\mathrm{mL}^{-1}}$, respectively, in the BD group and $2.1,11.6$ and $5.5 \mathrm{mg} \cdot \mathrm{mL}$ 1 , respectively, in the ICS group. After 4 weeks, this effect was significantly attenuated in both groups with a PC20 before, 1 and $12 \mathrm{~h}$ postdose of $3.3,10.9$ and $7.1 \mathrm{mg} \cdot \mathrm{mL}^{-1}$, respectively, in the BD group and $2.1,5.0$ and $2.3 \mathrm{mg} \cdot \mathrm{mL}^{-1}$, respectively, in the ICS group. This loss of protective effect was of similar magnitude in both groups. Respiratory symptoms, rescue $\beta_{2}$-agonist use and baseline FEV1 did not change significantly throughout the study in both groups.

In conclusion, the bronchoprotective effect of salmeterol decreased with regular use both 1 and $12 \mathrm{~h}$ postdose; inhaled corticosteroids did not prevent this reduction. However, the development of tolerance was not associated with loss of asthma control. Eur Respir J 1998; 11: 1091-1097.
Le Centre Québécois d'Excellence en Santé Respiratoire, *Unité de Recherche, Centre de Pneumologie de l'Hôpital Laval, Université Laval, Sainte-Foy, and +Service de Pneumologie, Hôpital du SacréCoeur, Montréal, Québec, Canada.

Correspondence: L-P. Boulet

Hôpital Laval

2725, Chemin Sainte-Foy, Sainte-Foy Québec G1V 4G5

Canada

Fax: 4186564762

Keywords: Asthma

inhaled corticosteroid

long-acting $\beta_{2}$-adrenoceptor agonists tolerance to bronchoprotective effects

Received: March 251997

Accepted after revision January 201998

Supported by Glaxo Wellcome Canada Bureau d'affaires du Québec and the Fonds de la Recherche en Santé du Québec (FRSQ-Industry program)
Asthma is an airway inflammatory disease characterized by airway hyperresponsiveness and variable airflow obstruction $[1,2]$. $\beta_{2}$-adrenoceptor agonists are the drugs prescribed most frequently for symptomatic relief of asthma symptoms. They demonstrate protective effects against a variety of stimuli, including exercise, cold air and methacholine or histamine-induced bronchoconstriction [3-5]. Tolerance to bronchodilator properties of short-acting $\beta_{2}$ adrenoceptor agonists has been documented, although it is not generally considered to be clinically significant $[6,7]$. Furthermore, tolerance to the bronchoprotective effects of agents such as terbutaline has been shown following their regular use [8].

Salmeterol, a long-acting $\beta_{2}$-adrenoceptor agonist, has bronchodilator effects lasting at least $12 \mathrm{~h}[4,5,9]$. As for short-acting agents, a reduction in the bronchoprotective effects of salmeterol after regular use has been reported after stimuli such as methacholine and exercise [10-13].
In one of the initial studies exploring changes in salmeterol protective effects over time, B00тH et al. [14], however, reported no significant loss of protective effect of salmeterol against methacholine-induced bronchoconstriction 12 $h$ post-challenge in a group of moderate asthmatic subjects. Interestingly, most of these patients were on inhaled corticosteroids, suggesting at that time that this medication could have protected against the loss of the protective effect of salmeterol. An alternative explanation is that the patients using $\beta_{2}$-agonists at an unspecified rate might have already developed a tolerance to this category of agents before the study, as a consequence of relatively regular use.

The mechanisms by which a possible tolerance to the bronchoprotective properties of $\beta_{2}$-adrenoceptor agonists occurs are uncertain. The influence of agents such as corticosteroids, previously shown to have antagonist effects on the development of tolerance of $\beta_{2}$-adrenoceptor 
agonist receptors in vitro, had not been explored until recently, and their influence on this phenomenon remains to be further defined [15-18]. A study by KaLRA et al. [18] showed that tolerance to the acute bronchoprotective effects of salmeterol could be observed after only two doses in asthmatic subjects on inhaled corticosteroids and persisted after the seventh dose. This reduction in bronchoprotective effect was observed as soon as $1 \mathrm{~h}$ after dosing with salmeterol $[10,18]$. The effect of corticosteroids on the tolerance to the bronchoprotective effects of salmeterol should, therefore, be examined further over a longer time-period, and the clinical relevance of reduced bronchoprotection on the control of asthma and medication needs to be documented.

The objectives of this study were to determine the magnitude of tolerance to the protective effects of salmeterol on methacholine-induced bronchoconstriction during chronic use and the influence of regular use of inhaled corticosteroids on this phenomenon. Furthermore, we wanted to document the clinical relevance of this effect, if any, in terms of increase in respiratory symptoms, rescue bronchodilator need and airflow obstruction.

\section{Methods}

\section{Subjects}

Thirty two nonsmoking asthmatic subjects (13 males and 19 females), aged 18-62 yrs (mean \pm sem: $39.1 \pm 2.9$ yrs) took part in this study. Their asthma was mild to moderate. They were divided into two groups according to their maintenance medication needs: bronchodilator (BD) alone $(n=16)$ or supplemented by inhaled corticosteroids (ICS) $(n=16)$.

\section{Inclusion criteria}

Patients were considered eligible for this study if they were aged 18-65 yrs, had been diagnosed with allergic or nonallergic asthma in accordance with the definition of the American Thoracic Society [19] and had required treatment during the past 6 months. Forced expiratory volume in one second (FEV1) had to be $>60 \%$ of the predicted value after having witheld inhaled bronchodilators for at least $8 \mathrm{~h}$, and baseline provocative concentration of methacholine inducing a $20 \%$ fall in FEV1 (PC20) had to be $<8 \mathrm{mg} \cdot \mathrm{mL}^{-1}$. In the ICS group, the minimum and maximum daily dose of ICS had to be at least $400 \mu \mathrm{g}$ but not greater than $1,500 \mu \mathrm{g}$ of beclomethasone or equivalent.

\section{Exclusion criteria}

Patients were ineligible for this study under the following conditions: documented or suspected viral or bacterial infection of the upper or lower respiratory tract within 4 weeks of the study; cardiovascular or systemic diseases; hospitalization within 4 weeks prior to the first visit; abnormal chest radiograph; use of theophylline, ipratropium or oral corticosteroids within 1 month before the study; or history of hypersensitivity reaction to any $\beta_{2}$-adrenoceptor agonist. Pregnant or breast-feeding women and those without adequate contraception were excluded. Those who had smoked within the past year or had any other condition considered by the investigator as potentially interfering with the study were not included.

Permitted medications included rescue salbutamol and "on demand" cromoglycate or nedocromil; bronchodilators (other than study medication and rescue salbutamol), oral corticosteroids, regular sodium cromoglycate, nedocromil, ketotifen, hypnotics, sedatives and any other experimental medication were not permitted. In the ICS group, the dose of this agent had to be kept constant throughout the study.

\section{Ethics criteria}

The protocol was approved by the Laval and SacréCoeur Hospital Ethics Committees and all subjects provided written, informed consent.

\section{Study design}

This was a 14-week double-blind, placebo-controlled, crossover study. After a 2 week run-in period, each subject of the two groups received salmeterol $50 \mu \mathrm{g}$ or a placebo twice daily during two randomly determined treatment phases of 4 weeks each. A 2 week washout period separated the two treatments, and another followed the second treatment period at the end of the trial.

During the study, the subjects came to the laboratory on the entry day (day -14), on days $0,28,42$ and 70 of the treatment period, and at the end of the study (day 84). On days -14 and 84 baseline expiratory flows and methacholine responsiveness were measured. Both peak expiratory flows (PEF) and respiratory symptoms were recorded twice daily (morning and evening), throughout the study period. Respiratory symptoms were graded on a scale from 0 to 5 ( 0 nothing, 1 very light, 2 light, 3 moderate, 4 severe and 5 very severe). Rescue bronchodilator use (salbutamol) was noted on the diary card.

On the first (days 0 and 42) and last (days 28 and 70) days of active and placebo treatment periods, subjects had the following measurements: baseline expiratory flows; and methacholine challenges $1 \mathrm{~h}$ prior to inhalation of study drug and at 1 and $12 \mathrm{~h}$ after taking placebo or salmeterol, according to randomization. One hour separated the beginning of the first methacholine and treatment administration. $\mathrm{PC} 20$ on days -14 and 0 had to be within 1.6 doubling concentrations or the subject was withdrawn from the study. Baseline PC20 (-1 h) on day 42 had to be within 1.6 doubling concentrations of PC20 on day -14 .

During the treatment period, the subjects stopped their study medication $48 \mathrm{~h}$ before and their rescue medication (salbutamol) $8 \mathrm{~h}$ before their visits to the laboratory. Compliance with the medication was checked by weighing the canisters.

\section{Spirometry and bronchodilator response}

Measurements of FEV1 and forced vital capacity (FVC) were performed according to standard guidelines. The best of three reproducible measurements was recorded on baseline and at each visit, before methacholine challenges. 
Bronchodilation induced by the study medications was assessed $1 \mathrm{~h}$ post-dosing, immediately before the next methacholine challenge $(+1 \mathrm{~h})$.

\section{Methacholine challenges}

Methacholine challenges were performed according to the method described by JUNIPER et al. [20]. We added the measurement of FVC at baseline, after saline, and after doses inducing a $>10 \%$ fall in FEV1, in order to determine the FVC at a $20 \%$ fall in FEV1 as an indirect measurement of maximal bronchodilator response [21]. On day 0 and later, the tests were started at 3 doubling concentrations lower than the PC20 measured on day -14. For the determination of $\mathrm{PC} 20$, the percentage fall in FEV1 was calculated from the post-saline value.

\section{Sample size and data analysis}

The two treatments were compared for the primary response variable $\mathrm{Y}$, defined as changes in bronchoprotection at 1 and $12 \mathrm{~h}$. Allowing for a $25 \%$ rate of attrition, the sample size calculation was 30 . This sample size (15 subjects in each group) provided $80 \%$ power for detecting a difference at the $5 \%$ level, where the two treatments were considered equivalent if the mean (or median) of the higher treatment was less than 1.5 times the mean (or median) of the lower treatment. This is for a two-sided test at the $5 \%$ significance level and is based on an estimated standard deviation of $\log (\mathrm{Y}$ (post-treatment)) - $\log (\mathrm{Y}$ (pre-treatment)) equal to 0.21 .

Inferential analyses were performed to assess comparability of the treatment groups. The primary measure of efficacy was the protective effect of each treatment on methacholine-induced bronchoconstriction 1 and $12 \mathrm{~h}$ post-treatment. This was defined as ((change in number of double concentrations of methacholine): treatment A) PC20 (day 0 (1 or 12 h)) compared with PC20 (day 0 (-1 h))/PC20 (day 28 (1 or 12 h)) compared with PC20 (day 28 $(-1 \mathrm{~h})$ ). For treatment B, the same approach was used, by changing day 0 and day 28 to day 42 and day 70 , respectively.

Repeated measures of crossover design were used to compare treatment groups with respect to the protective effect on methacholine-induced bronchoconstriction at 1 and $12 \mathrm{~h}$ compared to pre-dose $(-1 \mathrm{~h})$, before, and after 4 weeks of treatment.

Changes in mean of the last 14 days of each treatment compared to the 14 days before treatment (either baseline or wash-out period) for symptoms, bronchodilator needs and PEF (morning-evening), have been analysed both in the ICS and BD groups.

\section{Results}

\section{Subjects' characteristics and withdrawals}

Thirty of the 32 enrolled subjects completed the study. One subject in the BD group (while on salmeterol) did not complete the study because of an exacerbation of asthma on day 42 that required therapy with ICS and one subject in the ICS group (while on salmeterol) withdrew on day 28 for a nonrespiratory condition limiting his availability for the study. These subjects were not included in the analysis. As assessed on screening day, the ICS group was slightly older $(\mathrm{p}=0.015)$ and had a longer duration of asthma than the BD group, but it was not significant (table 1). Thirteen subjects were atopic in the BD group compared to seven in the ICS group; mean baseline FEV1 (\% predicted) was slightly higher in the BD $(87.1 \pm 3.8 \%)$ than in the ICS $(76.3 \pm 2.6 \%)$ group $(\mathrm{p}=0.03)$.

\section{Changes in symptoms and rescue bronchodilator use}

In both groups, mean symptom scores and rescue bronchodilator use during the last 2 weeks of each treatment were low and not different from baseline or washout when on salmeterol or placebo $(\mathrm{p}>0.05)$. During the run-in period, mean daily number of rescue salbutamol inhalations was 1.9 in the ICS group and 0.63 in the BD group.

\section{Expiratory flows}

Salmeterol increased morning PEF in both groups (pð 0.03 ) and evening PEF in the ICS group $(p=0.005)$, but not in the BD group $(\mathrm{p}=0.27)$.

The mean premethacholine FEV 1 values (day -14 or time -1 h of days $0,28,42,70$ and 84 ) recorded during the study are shown in figure 1 . In both groups, mean FEV1 before salmeterol was not different from FEV1 before placebo at the beginning of each treatment period (day 0 or 42) (BD group: $85.3 \pm 3.7 \%$ versus $87.0 \pm 3.5 \%$; ICS group: $76.7 \pm 2.5 \%$ versus $77.3 \pm 2.8 \%$ ).

The mean increases in FEV1 (expressed as a percentage of predicted) $1 \mathrm{~h}$ after salmeterol (post-methacholine challenge) compared with baseline pre-dose values on the first day of treatment were: BD $19 \pm 1.6 \%$ and ICS $22 \pm 2.7 \%$ (pð0.001 for both, compared to pre-dosing FEV1 on time $0)$. On the last day of treatment with salmeterol, these values were: BD $17 \pm 1.8 \%$ and ICS $13 \pm 2.9 \%$ pred $(\mathrm{p}=0.004$ and $\mathrm{p}=0.23$, respectively). There was no significant difference in the percentage change in FVC after methacholine challenges for the two groups, before and 1 and $12 \mathrm{~h}$ posttreatment, whatever the treatment period (data not shown).

\section{Airway responsiveness}

PC20 was not different on baseline tests (day -14, first days of treatment (-1 h) and follow-up day 84). Geometric mean $\mathrm{PC} 20$ at the beginning of both treatment periods showed no significant difference in the two groups (fig. 2). PC20 before and after the placebo period did not change from baseline for either group regardless of the time of day at which the methacholine test was performed.

The first inhalation of salmeterol afforded a significant protection against methacholine-induced bronchoconstriction in both groups up to $12 \mathrm{~h}$ as compared with the value at $-1 \mathrm{~h}$, although it was significantly better in the ICS group (table 2). In both groups, salmeterol significantly reduc- ed the bronchial response to methacholine after 4 weeks of 
Table 1. - Characteristics of the subjects

\begin{tabular}{|c|c|c|c|c|c|c|c|c|c|}
\hline $\begin{array}{l}\text { Subject } \\
\text { No. }\end{array}$ & $\begin{array}{l}\text { Sex } \\
\mathrm{M} / \mathrm{F}\end{array}$ & Age & Atopy & $\begin{array}{c}\text { Asthma } \\
\text { duration } \\
\text { yrs }\end{array}$ & $\begin{array}{r}\mathrm{Bas} \\
\mathrm{Fl} \\
\mathrm{L}(\%\end{array}$ & $\begin{array}{l}\text { line } \\
\text { V1 } \\
\text { pred) }\end{array}$ & $\begin{array}{r}\mathrm{Ba} \\
\mathrm{F} \\
\mathrm{L}(9\end{array}$ & $\begin{array}{l}\text { eline } \\
\text { VC } \\
\text { pred) }\end{array}$ & $\begin{array}{c}\text { Daily ICS } \\
\text { dose } \\
\mu \mathrm{g}\end{array}$ \\
\hline Salbuta & & & & & & & & & \\
\hline 1 & $\mathrm{~F}$ & 18 & + & 5 & 1.97 & (67) & 3.01 & (95) & 0 \\
\hline 2 & M & 25 & + & 24 & 3.87 & (92) & 4.49 & (87) & 0 \\
\hline 5 & M & 33 & + & 10 & 2.95 & (77) & 4.12 & (87) & 0 \\
\hline 8 & M & 28 & + & 7 & 3.60 & (84) & 4.55 & (86) & 0 \\
\hline 9 & M & 22 & + & 12 & 3.24 & (82) & 3.65 & (78) & 0 \\
\hline 10 & $\mathrm{~F}$ & 18 & + & 4 & 3.17 & (103) & 3.77 & (112) & 0 \\
\hline 12 & M & 22 & + & 14 & 3.76 & $(92)$ & 4.43 & (92) & 0 \\
\hline 15 & $\mathrm{~F}$ & 22 & & 1 & 2.60 & (81) & 3.50 & (91) & 0 \\
\hline 19 & $\mathrm{~F}$ & 50 & + & 7 & 1.90 & (66) & 2.75 & (78) & 0 \\
\hline 21 & $\mathrm{~F}$ & 51 & & 8 & 1.85 & (68) & 2.59 & (79) & 0 \\
\hline 23 & $\mathrm{~F}$ & 30 & + & 2 & 3.39 & (112) & 4.17 & (118) & 0 \\
\hline 25 & $\mathrm{~F}$ & 23 & + & 6 & 3.63 & (113) & 4.10 & (110) & 0 \\
\hline 26 & $\mathrm{~F}$ & 22 & + & 16 & 3.30 & (94) & 4.00 & (97) & 0 \\
\hline 27 & $\mathrm{~F}$ & 59 & + & 11 & 2.19 & (93) & 2.91 & (101) & 0 \\
\hline 28 & $\mathrm{~F}$ & 42 & + & 16 & 2.00 & (82) & 2.69 & (95) & 0 \\
\hline Mean & & 31.0 & & 9.5 & 2.89 & (87.1) & 3.65 & (93.7) & \\
\hline$\pm \mathrm{SEM}$ & & \pm 3.4 & & \pm 1.6 & \pm 0.2 & $( \pm 3.8)$ & \pm 0.2 & $( \pm 3.2)$ & \\
\hline Inhaled & & & & & & & & & \\
\hline 3 & M & 62 & & 20 & 2.21 & (69) & 2.91 & (71) & 400 \\
\hline 4 & M & 20 & + & 5 & 3.25 & (78) & 5.03 & (105) & 500 \\
\hline 6 & M & 30 & + & 20 & 3.24 & (87) & 4.67 & (102) & 1000 \\
\hline 7 & $\mathrm{~F}$ & 26 & + & 20 & 2.26 & (80) & 3.42 & (102) & 800 \\
\hline 11 & M & 56 & & 15 & 2.96 & (80) & 4.28 & (86) & 1000 \\
\hline 13 & $\mathrm{~F}$ & 31 & + & 4 & 2.78 & (88) & 4.04 & (105) & 500 \\
\hline 14 & $\mathrm{~F}$ & 44 & + & 1 & 1.82 & (67) & 2.46 & $(75)$ & 800 \\
\hline 16 & M & 20 & + & 20 & 3.84 & (97) & 5.22 & (114) & 1000 \\
\hline 18 & $\mathrm{~F}$ & 59 & & 10 & 1.80 & (73) & 2.20 & (72) & 400 \\
\hline 20 & $\mathrm{~F}$ & 62 & + & 8 & 1.60 & (66) & 1.89 & (63) & 400 \\
\hline 22 & $\mathrm{~F}$ & 62 & & 23 & 1.88 & (76) & 2.82 & (92) & 500 \\
\hline 24 & M & 58 & & 5 & 2.89 & (80) & 4.20 & (93) & 500 \\
\hline 30 & M & 33 & & 9 & 2.37 & (62) & 3.86 & (84) & 800 \\
\hline 31 & $\mathrm{~F}$ & 62 & & 50 & 1.35 & (61) & 2.05 & (75) & 500 \\
\hline 32 & $\mathrm{~F}$ & 54 & & 22 & 2.52 & (85) & 3.72 & (102) & 500 \\
\hline Mean & & 45.3 & & 15.5 & 2.45 & (76.3) & 3.52 & (89.4) & 640 \\
\hline \pm SEM & & \pm 4.3 & & \pm 3.9 & \pm 0.2 & $( \pm 2.7)$ & \pm 0.3 & $( \pm 4.0)$ & \pm 60 \\
\hline
\end{tabular}

+: subject with at least one positive response to common aeroallergen; M: male; F: female; FEV1: forced expiratory volume in one second; \% pred: percentage of predicted value; FVC: forced vital capacity; ICS: inhaled corticosteroids.
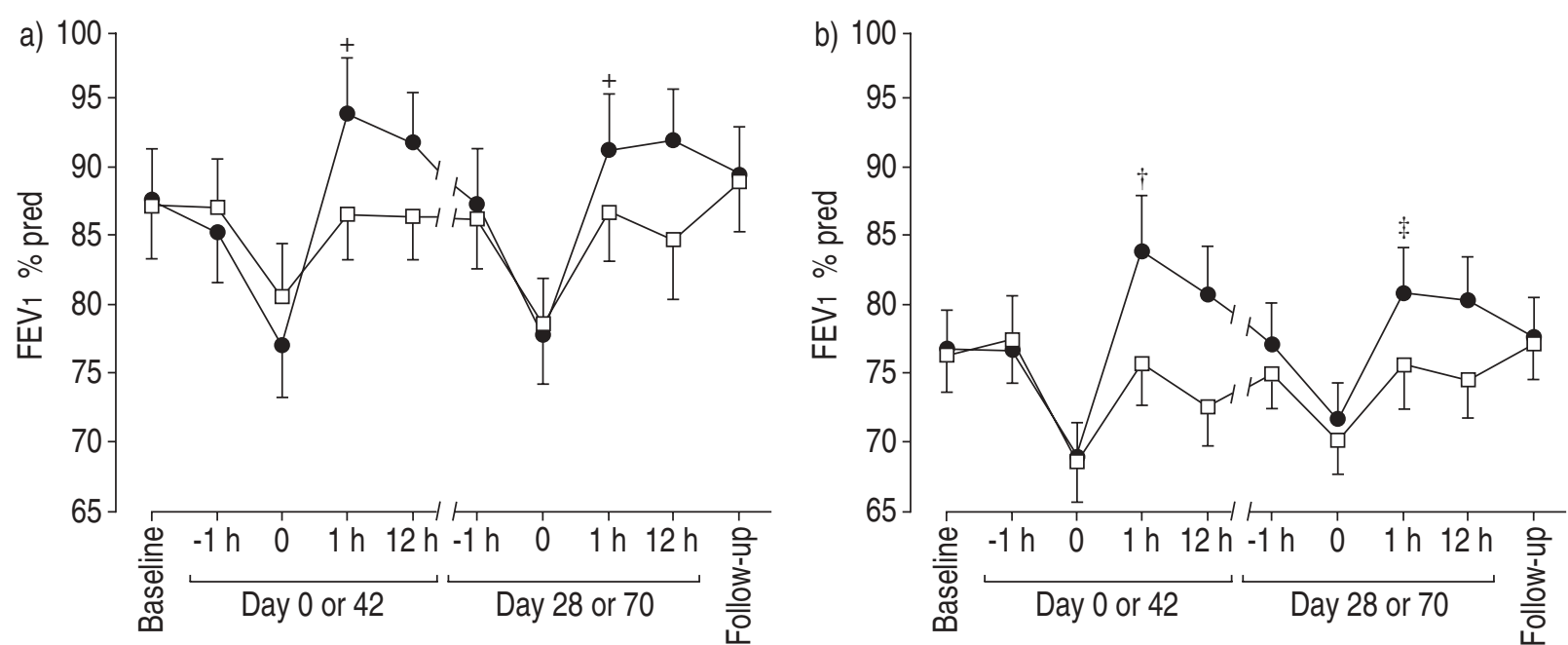

Fig. 1. - Changes of forced expiratory volume in one second (FEV1) during the study. FEV1 (\% predicted) was measured in a) the bronchodilator (BD) group and b) the inhaled corticosteroid (ICS) group at baseline (day -14), immediately before the methacholine challenge (-1 h), at the time salmeterol $(\bullet)$ or placebo $(\square)$ were inhaled, and then 1 and $12 \mathrm{~h}$ after the first day of treatment (day 0 or 42 ), and last day of treatment(day 28 or 70 ) and at follow-up (day 84). Values are presented as mean \pm SEM. FEV1 increased significantly after salmeterol on days 0 or 42 and 28 or 70 in the BD group and on days 0 or 42 in the ICS group (maximal increase in BD group: 19 and 17\%; maximal increase in ICS group: 22 and $13 \%$. ${ }^{+}$: pð0.004; ${ }^{\dagger}$ : $\mathrm{p}=0.001 ;: \mathrm{p}=0.23$ 

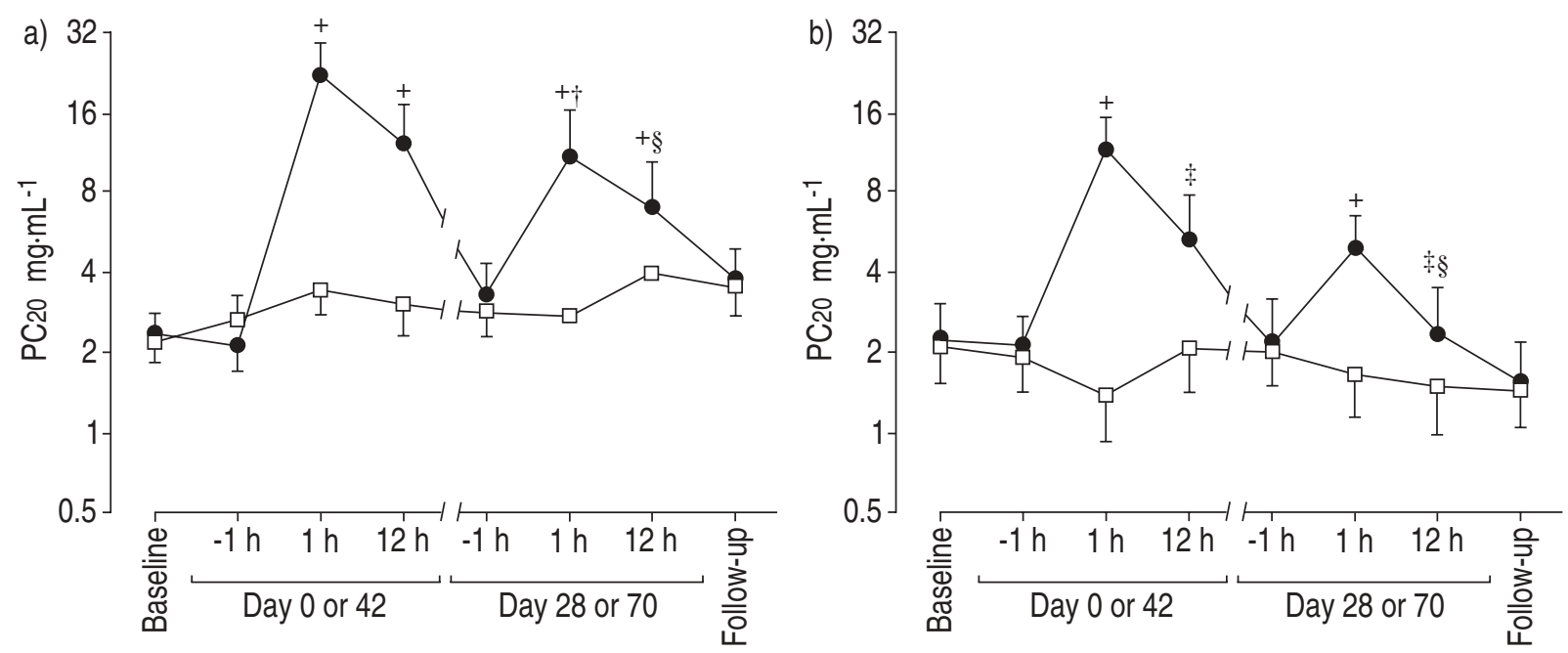

Fig. 2. - Variations of provocative concentration of methacholine causing a $20 \%$ fall in forced expiratory volume in one second (PC20) during the study. Methacholine response was measured in a) the BD group and b) the ICS group at baseline (day -14 ); $1 \mathrm{~h}$ before and 1 and $12 \mathrm{~h}$ after inhalation of salmeterol (•) or placebo ( $\square$ ) on the first day of treatment (day 0 or 42), last day of treatment (day 28 or 70) and at follow-up (day 84). Values are presented as geometric mean \pm SEM. In both groups, salmeterol led to a significant reduction in airway responsiveness up to $12 \mathrm{~h}$ on the first day and after 28 days of treatment. After 4 weeks of treatment, this protective effect of salmeterol was significantly attenuated. + : pð0.0002 compared to baseline; $¥$ : $\mathrm{p}=0.03$ compared to $-1 \mathrm{~h}$ values; ${ }^{\dagger}:$ pð0.002 compared to baseline; $\S$ : pð0.04 compared to corresponding values on first day of treatment. For further definitions of abbreviations see legend to figure 1 .

Table 2. - Changes in the bronchoprotective effect of salmeterol expressed as the change in provocative concentration of methacholine causing a $20 \%$ fall in forced expiratory volume in one second $\left(\triangle \mathrm{PC}_{20}\right)$

\begin{tabular}{|c|c|c|c|c|}
\hline & \multicolumn{2}{|c|}{ Day 0 or 42} & \multicolumn{2}{|c|}{ Day 28 or 70} \\
\hline & $\mathrm{h}$ & 12 & $\mathrm{~h}$ & 17 \\
\hline \multicolumn{5}{|l|}{ D group } \\
\hline & & & \pm 0.18 & 20 \\
\hline & & & & \\
\hline \multicolumn{5}{|l|}{ oup } \\
\hline & & & & \\
\hline & & 100 & I0.J3 & $0.10-1$ \\
\hline \multicolumn{5}{|c|}{ 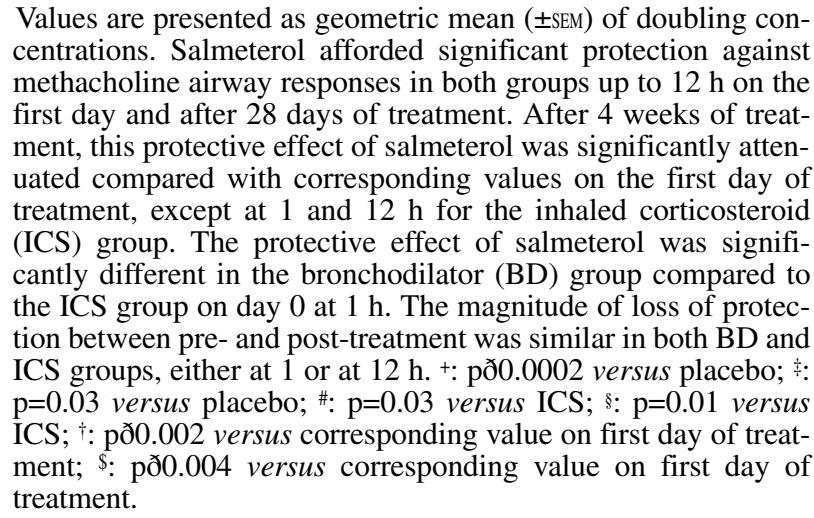 } \\
\hline
\end{tabular}

treatment at 1 and $12 \mathrm{~h}$ post-dosing. However, in the BD group, after 4 weeks of salmeterol treatment (day 28 or 70), the protective effect of salmeterol was significantly attenuated compared with the corresponding value on the first day of treatment ( $\mathrm{p}=0.002$ at $1 \mathrm{~h}$ and 0.04 at $12 \mathrm{~h}$ ).

In the ICS group the protective effect of salmeterol was also attenuated at 1 and $12 \mathrm{~h}(\mathrm{p}=0.01)$, although it did not reach statistical significance at $1 \mathrm{~h}(\mathrm{p}=0.22$; table 2 and fig. 2). Finally, the loss of protection between pre- and post-treatment was of the same magnitude in both the BD and ICS groups, at 1 or at $12 \mathrm{~h}(\mathrm{p}=0.30$ at $1 \mathrm{~h}$ and $\mathrm{p}=0.57$ at $12 \mathrm{~h}$; table 2 ).

\section{Discussion}

Observations on the development of a tolerance to the protective effects of long-acting $\beta_{2}$-adrenoceptor agonists on airway responsiveness raised concerns about the longterm use of these drugs. This phenomenon was observed with both short-acting and long-acting $\beta_{2}$-adrenoceptor agonists, following different stimuli such as methacholine and exercise [7, 13, 22].

The present study evaluated the effect of chronic use of salmeterol on methacholine-induced bronchoconstriction in two groups of asthmatic subjects, one using only bronchodilators and the other inhaled corticosteroids. In both groups, although the degree of bronchoprotection was variable from one subject to another, we observed a decrease in the bronchoprotective effect of salmeterol after 4 weeks of regular use, 1 and $12 \mathrm{~h}$ after dosing. However, although it was reduced, the protective effect of salmeterol persisted after 4 weeks and was not associated with a loss of asthma control whatever the group, suggesting that it has little or no clinical significance.

Our study is in keeping with previous studies, such as that of Cheung et al. [13], who showed that the protective effects of salmeterol against methacholine-induced bronchoconstriction were diminished after 8 weeks on regular salmeterol $50 \mu \mathrm{g}$ twice daily. O'ConNor et al. [8], also reported that regular use of inhaled terbutaline $(500 \mu \mathrm{g}$ q.i.d.) for 7 days, reduced the bronchoprotective effect of a single dose of terbutaline from 2.7 to 2.2 doubling doses. This reduction was even more marked with inhaled adenosine monophosphate (AMP) (1.7 doubling dose reduction compared with 3.8 initially).

Воотн et al. [14], showed that salmeterol provided a significant protective effect of small magnitude against methacholine-induced bronchoconstriction $12 \mathrm{~h}$ post-challenge in a group of moderate asthmatic subjects. There was no evidence of tolerance to this protective effect after 8 weeks of regular use and no rebound increase in air- way responsiveness after stopping salmeterol. These data 
might have suggested that the reduction of the bronchoprotective effects of long-acting $\beta_{2}$-adrenoceptor agonists could be short-lasting or that the effects might be nullified by ICS, as most of their subjects were using those agents. The observations were supported by previous data suggesting that corticosteroids may antagonize the development of tolerance of $\beta_{2}$-adrenoceptor agonist receptors in vitro [13]. Long-acting $\beta_{2}$-adrenoceptor agonists are currently recommended with concomitant use of ICS [23, 24]. It seemed mandatory for us to evaluate whether tolerance to the bronchoprotective effect of these agents could still be observed in the presence of anti-inflammatory therapy, and if it was associated with increased asthma symptoms.

The weak bronchoprotection observed in the study by Bоотн et al. [14] and in our study may also be related to the fact that subjects were already taking relatively regular $\beta_{2}$-adrenocepter agonists before the study. Tolerance to the bronchoprotective effect of $\beta_{2}$ agonist is very sensi-tive to low doses and short duration of inhaled $\beta_{2}$ agonist use. Subjects of the ICS group used a higher dose of in-haled $\beta_{2}$-adrenocepter agonists and, therefore, their relatively low protection at the onset of the study period could have been due to prior $\beta_{2}$-adrenocepter agonist use.

Recently, KaLRA et al. [18] found that tolerance to the bronchoprotective effects of $\beta_{2}$-adrenoceptor agonists, especially if long acting, develops rapidly and is sustained over a continuous twice daily use over a period of seven doses. This last study also showed cross-tolerance with the short-acting $\beta_{2}$-adrenoceptor agonist. Similarly, but for a longer time-period, using a cross-over design to compare the effects of a 4 week period of salmeterol with a placebo and using pre-post dosing methacholine measurements to avoid the possibility of inter-day spontaneous variation in airway responsiveness, we found that such a tolerance to the bronchoprotective effects of salmeterol had developed at 4 weeks whether corticosteroids were used or not. Therefore, chronic use of ICS does not seem to prevent this phenomenon.

The mechanisms of the bronchoprotection afforded by $\beta_{2}$-adrenoceptor agonists are still incompletely understood, and it is possible that such effects are due, at least in part, to the influence of these agents on inflammatory cell mediator release and plasma transudation [25]. Salmeterol afforded less bronchoprotection in our subjects on ICS than in the BD group. This may, perhaps, be explained by the fact that inhaled corticosteroids act via a mechanism similar to that of salmeterol (e.g. airway oedema?), although the effects of steroids seem to result from a reduction of airway responsiveness from their action on many components of inflammation. It may also be due to greater asthma severity in the ICS group, although the pattern and magnitude of reduction of the bronchoprotective effect were similar to those found in patients not using ICS.

In a double-blind parallel study, Воотн et al. [26] recently reported a similar reduction in the protective effect against methacholine induced bronchoconstriction $1 \mathrm{~h}$ after dosing after 4 and 8 weeks of regular treatment with salmeterol $(50 \mu \mathrm{g}$ b.i.d.) in 31 subjects taking ICS. They did not observe any reduction in the bronchodilator effect of salmeterol at $1 \mathrm{~h}$ after dosing. These results were subsequently confirmed by YATES et al. [27], using a placebocontrolled treatment with budesonide for 3 weeks. Hence, our own data and these previous studies convincingly show the absence of protection by inhaled steroids against the development of tolerance to the bronchoprotecting effects of long-acting $\beta$-agonists.

Finally, although we observed a reduction of bronchoprotection in our two groups, it was still present and significant at 4 weeks. The pattern of change in bronchoprotection was similar and of the same magnitude in both groups. The lack of significance for the loss of protective effect in the ICS group on the last day of treatment may be related to the degree of reduction in bronchoprotection with regard to the number of patients studied. This reduction was not accompanied by an increase in medication needs or symptoms. It is possible that the residual bronchoprotection is sufficient to antagonize the effects of most triggers of bronchoconstriction. However, the variation and consequences of this reduction of protection remain to be further documented, particularly in the long-term (e.g., over a few months).

In conclusion, we showed that the protective effect of salmeterol decreases, but does not disappear, with regular use, whether airway response is measured at 1 or $12 \mathrm{~h}$ post-salmeterol inhalation, and that inhaled corticosteroids do not prevent this decrease. Moreover, this loss of bronchoprotective effect was not associated with an increase in asthma symptoms.

Acknowledgements: The authors are grateful to S. Simard and H. Ghezzo for their help with the preparation of the protocol and statistical analysis, and to L. Schubert for reviewing the manuscript.

\section{References}

1. McFadden ER Jr, Gilbert IA. Asthma. $N$ Engl $J$ Med 1993; 327: 1928-1937.

2. Djukanovic R, Roche WR, Wilson JW, et al. Mucosal inflammation in asthma. Am Rev Respir Dis 1990; 142: 434-457.

3. Cockcroft DW, Murdock KY. Comparative effects of inhaled salbutamol, sodium cromoglycate and beclomethasone dipropionate on allergen-induced early asthmatic responses, late asthmatic responses, and increased bronchial responsiveness to histamine. J Allergy Clin Immunol 1987; 79: 734-740.

4. Boulet LP. Long-versus short-term $\beta_{2}$-agonists: implications for asthma management. Drugs 1994; 47 (2): 207222.

5. Malo JL, Ghezzo H, Trudeau C, L'Archevêque J, Cartier A. Salmeterol, a new inhaled beta 2-adrenergic agonist, has a longer blocking effect than albuterol on hyperventilation-induced bronchoconstriction. J Allergy Clin Imтиnol 1992; 89: 567-574.

6. Conolly ME, Hui Kit Ka, Borts SE, Jenne JW. Beta-adrenergic tachyphylaxis (desensitization) and functional antagonism. In: Jenne JW, Murphy S, eds. Drug Therapy for Asthma. New York, Marcel Dekker, 1987; pp. 259-296.

7. Grove A, Lipworth BJ. Tolerance with $\beta_{2}$-adrenoceptor agonists: time for reappraisal. Br J Clin Pharm 1995; 39: 109-118.

8. O'Connor BJ, Aikman SL, Barnes PJ. Tolerance to the nonbronchodilator effects of inhaled $\beta_{2}$-adrenoceptor agonists in asthma. N Engl J Med 1992; 327: 1204-1208.

9. Ullman A, Hedner J, Svedmyr N. Inhaled salmeterol and salbutamol in asthmatic patients. Am Rev Respir Dis 1990; 142: 571-575.

10. Bhagat R, Kalra S, Swystun VA, Cockcroft DW. Rapid 
onset of tolerance to bronchoprotective effect of salmeterol. Chest 1995; 108: 1235-1239.

11. Grove A, Lipworth BJ. Effects of prior treatment with salmeterol and formoterol on airway and systemic beta-2 responses to fenoterol. Thorax 1996; 51: 585-589.

12. Verbene AAPH, Hop WCJ, Creyghton FBM, et al. Airway responsiveness after a single dose of salmeterol and during four months of treatment in children with asthma. J Allergy Clin Immunol 1996; 97: 938-946.

13. Cheung D, Timmers MC, Zwinderman AH, Bel EH, Dijkman JH, Sterk PJ. Long-term effects of a long-acting $\beta_{2}$-adrenoceptor agonist, salmeterol, on airway hyperresponsiveness in patients with mild asthma. $N$ Engl J Med 1992; 327: 1198-1203.

14. Booth H, Fishwick K, Harkawat R, Dereveux G, Hendrick DJ, Walters EH. Changes in methacholine-induced bronchoconstriction with the long acting $\beta_{2}$-adrenoceptor agonist salmeterol in mild to moderate asthmatic patients. Thorax 1993; 48: 1121-1124.

15. Tattersfield AK. Tolerance to beta-adrenoceptor agonists. Bull Eur Physiopathol Respir 1985; 21S: 1-5.

16. Sears MR. Long-acting beta-agonists, tachyphylaxis, and corticosteroids. Chest 1996; 109: 862-864.

17. Svedmyr N. Action of corticosteroids on adrenergic receptors. Clinical aspects. Am Rev Respir Dis 1990; 141: (Suppl.): S31-38.

18. Kalra S, Swystun VA, Bhagat R, Cockcroft DW. Inhaled corticosteroids do not prevent the development of tolerance to the bronchoprotective effect of salmeterol. Chest 1996; 109: 953-956.
19. American Thoracic Society Board of Directors. Standards for the diagnosis of patients with COPD and asthma. Am Rev Respir Dis 1987; 136: 225-244.

20. Juniper E, Cockcroft DW, Hargreave FE. Histamine and methacholine inhalation tests: tidal breathing method. Laboratory procedure and standardization. Canadian Thoracic Society, AB Draco, 1992.

21. Gibbons WJ, Sharma AJ, Lougheed D, Macklem PT. Detection of excessive bronchoconstriction in asthma. Am J Respir Crit Care Med 1996; 153: 582-589.

22. Ramage L, Lipworth BJ, Ingram CG, Cree IA, Dhillon DP. Reduced protection against exercise induced bronchoconstriction after chronic dosing with salmeterol. Resp Med 1994; 88: 363-368.

23. International consensus report on diagnosis and treatment of asthma. Clin Exp Allergy 1992; Supp. 1: 1-72.

24. Ernst P, FitzGerald M, Spier S. Canadian Asthma Consensus Conference: summary of recommendations. Can Respir J 1996; 3: 89-100.

25. Persson CGA, Ekman M, Erjefalt I. Vascular anti-permeability effect of $\beta_{2}$-receptor agonists and theophylline in the lung. Acta Pharmacol Toxicol 1979; 44: 216-220.

26. Booth H, Bish R, Walters J, Whitehead F, Walters EH. Salmeterol tachyphylaxis in steroid treated asthmatic subjects. Thorax 1996; 51: 1100-1104.

27. Yates DH, Kharitonov SA, Barnes PJ. An inhaled glucocorticoid does not prevent tolerance to the bronchoprotective effect of a long-acting beta-2-agonist. Am J Respir Crit Care Med 1996; 154: 1603-1607. 